\title{
The insulinogenic effect of whey protein is partially mediated by a direct effect of amino acids and GIP on $\beta$-cells
}

\author{
Albert Salehi ${ }^{1}$, Ulrika Gunnerud ${ }^{2,5^{*}}$, Sarheed J Muhammed ${ }^{1}$, Elin Östman ${ }^{2}$, Jens J Holst ${ }^{3}$, Inger Björck ${ }^{2}$
} and Patrik Rorsman ${ }^{4}$

\begin{abstract}
Background: Whey protein increases postprandial serum insulin levels. This has been associated with increased serum levels of leucine, isoleucine, valine, lysine, threonine and the incretin hormone glucose-dependent insulinotropic polypeptide (GIP). We have examined the effects of these putative mediators of whey's action on insulin secretion from isolated mouse Langerhans islets.

Methods: Mouse pancreatic islets were incubated with serum drawn from healthy individuals after ingestion of carbohydrate equivalent meals of whey protein (whey serum), or white wheat bread (control serum). In addition the effect of individual amino acid combinations on insulin secretion was also tested. Furthermore, the stimulatory effects of whey serum on insulin secretion was tested in vitro in the absence and presence of a GIP receptor antagonist ((Pro(3))GIP[mPEG]).

Results: Postprandial amino acids, glucose-dependent insulinotropic polypeptide (GIP) and glucagon-like peptide 1 (GLP-1) responses were higher after whey compared to white wheat bread. A stimulatory effect on insulin release from isolated islets was observed with serum after whey obtained at $15 \mathrm{~min}(+87 \%, P<0.05)$ and $30 \mathrm{~min}(+139 \%$, $P<0.05)$ postprandially, compared with control serum. The combination of isoleucine, leucine, valine, lysine and threonine exerted strong stimulatory effect on insulin secretion $(+270 \%, P<0.05)$, which was further augmented by GIP ( $+558 \%$ compared to that produced by glucose, $P<0.05)$. The stimulatory action of whey on insulin secretion was reduced by the GIP-receptor antagonist (Pro(3)) GIP[mPEG]) at both 15 and 30 min (-56\% and $-59 \%$, $P<0.05)$.

Conclusions: Compared with white wheat bread meal, whey causes an increase of postprandial insulin, plasma amino acids, GIP and GLP-1 responses. The in vitro data suggest that whey protein exerts its insulinogenic effect by preferential elevation of the plasma concentrations of certain amino acids, GIP and GLP-1.
\end{abstract}

Keywords: Amino acids, GIP-antagonist, Incretins, Insulin release, In vitro, Isolated Langerhans islets, Whey

\section{Background}

Dairy products produce higher insulin responses (Insulin index, II, 90-98) than expected from their comparatively low glycemic indices (GI 15-30) [1,2]. Insulinogenic effects from dairy products have been observed in healthy subjects, both when ingested as a single meal

\footnotetext{
*Correspondence: ulrika.gunnerud@appliednutrition.lth.se

${ }^{2}$ Department of Applied Nutrition and Food Chemistry, Lund University,

Lund, Sweden

${ }^{5}$ Applied Nutrition and Food Chemistry, Lund University, P.O. Box 124, 22100 Lund, Sweden

Full list of author information is available at the end of the article
}

[1], and when included into a mixed meal [2,3]. The insulin-releasing capacity of dairy products has been attributed to the protein fraction, and both whey and casein have been shown to stimulate insulin secretion in healthy subjects $[4,5]$. Particularly the whey fraction and release of amino acids during digestion has been proposed to underlie the insulinogenic properties of milk [6]. Indeed, several amino acids are known to stimulate insulin secretion both in vivo and in vitro [7-13]. Previous work has shown that postprandial plasma concentrations of isoleucine, leucine, valine, lysine and threonine

\section{Biomed Central}


are elevated following a whey meal [4], and these amino acids have been implicated as mediators of the insulinogenic effect [6]. In addition, the incretin hormone GIP has been shown to be present at higher postprandial levels after ingestion of whey compared to white wheat bread (WWB) $[4,6,14]$, and may thus contribute to the insulinotropic effect.

The objective of this study was to investigate the mechanisms underlying the insulinogenic effect of whey protein. We aimed to determine whether or not serum responses of amino acids (isoleucine, leucine, valine, lysine and threonine) and GIP, following whey ingestion exerted their effects on insulin stimulation directly on the pancreatic $\beta$-cells. We have compared the effects of postprandial serum withdrawn from healthy individuals after ingestion of equi-carbohydrate portions of whey or white wheat bread (WWB), respectively, on insulin secretion in vitro. The impact of isoleucine, leucine, valine, lysine and threonine, as well as of a mixture thereof was studied using an in vitro model with isolated islets from mice [6]. In the light of our previous studies showing significant increases in serum GIP following oral administration of whey, in vitro insulin release in response to selected amino acids was tested with or without addition of a GIP antagonist [6].

\section{Materials and methods \\ Human meal studies \\ Serum for in vitro analysis of insulin secretion of Langerhans islets}

Six (4 M, $2 \mathrm{~W})$, non-smoking healthy volunteers, aged 20-30 y, with normal fasting blood glucose and body mass indices and without any history of previous drug treatment participated in the study. Two meals, whey protein and white wheat bread (WWB), matched with regard to carbohydrate content $(25 \mathrm{~g})$ were provided in the morning after an overnight fast. Lactose was the carbohydrate source in the whey meal, and starch in the WWB meal. The protein amount was $3.7 \mathrm{~g}$ in the WWB meal and $16.7 \mathrm{~g}$ in the whey meal. The participants were instructed to avoid alcohol, excessive physical activity and food rich in dietary fibers on the day before the test and to eat a standardized meal consisting of white wheat bread between 9 and $10 \mathrm{pm}$ and then nothing except small amounts of water. When reporting at the laboratory in the morning, a peripheral catheter was inserted into an antecubital vein and fasting blood was sampled (time 0). Thereafter, the test meal was served and completed within $12 \mathrm{~min}$. Coffee or tea $(150 \mathrm{ml})$ was served 15 min after start, and each subject maintained the same drink throughout the study. Blood samples were then taken 7.5, 15, 30 and $45 \mathrm{~min}$ after the start of the meal. Sera obtained after whey ingestion ("whey serum") and WWB ("control serum") were stored at $-20^{\circ} \mathrm{C}$ until analyzed. Blood samples were also taken at 0, 15, 30 and 45 min for analysis of free amino acids, GIP and GLP-1 in plasma. All test subjects gave their informed consent and were aware of the possibility of withdrawing from the study at any time. The study was approved by Ethics Committee of the Faculty of Medicine at Lund University.

\section{Serum for in vitro analysis of insulin secretion of Langerhans islets with or without GIP receptor antagonist ((Pro(3))GIP[mPEG])}

The meal study was performed in the same way as mentioned above, with the difference that it was 12 healthy test subjects $(7 \mathrm{~W}, 5 \mathrm{M})$. One test drink and one reference drink were included in the study, which were served as breakfast on two different occasions. The test drinks consisted of $18 \mathrm{~g}$ of whey protein. The reference drink was glucose in $250 \mathrm{~g}$ water. Blood samples were taken at 0,15 and $30 \mathrm{~min}$.

\section{Blood analysis}

Free amino acids were purified by mixing $200 \mu \mathrm{l} 10 \%$ sulfosalicylic acid with $800 \mu \mathrm{l}$ plasma to precipitate high molecular-weight proteins. The amino acids were then analyzed with an amino acid analyzer (LC 5001; Biotronik, München, Germany) by ion-exchange chromatography. The amino acids were separated by using standard lithium citrate buffers of $\mathrm{pH} 2.85,2.89,3.20$, 4.02 and 3.49. The post column derivatization was performed with ninhydrin [15].

Plasma glucose-dependent insulinotropic polypeptide (GIP) and glucagon-like peptide 1 (GLP-1) concentrations were measured after extraction of plasma with $70 \%$ ethanol. For the GIP radioimmunoassay [16], antiserum R65 (directed against the C-terminus) was used. Human GIP and ${ }^{125}$ I-labelled human GIP (70 Bq/nmol) were used for standards and tracer. The plasma concentrations of GLP1 were measured as previously reported [17] using antibodies directed against the amidated C-terminus of GLP-1 (code no. 89390) against standards of synthetic GLP-1 736 amide. For both assays, sensitivity was $<1 \mathrm{pmol} / \mathrm{l}$, the intra-assay $\mathrm{CV}$ was $<6 \%$ at $20 \mathrm{pmol} / \mathrm{l}$, and the recovery of standard (which was added to plasma before extraction) was $\approx 100 \%$ when corrected for losses inherent in the plasma extraction procedure.

\section{In vitro analysis of Langerhans islets Animals}

Female mice of the NMRI strain (B\&K Universal, Sollentuna, Sweden), weighing 25-30 g, were used for all experiments. The mice were fed a standard pellet diet (B\&K Universal, Sollentuna, Sweden) and tap water ad libitum. The mice were killed by cervical dislocation followed by decapitation (with ethical approval). 


\section{Drugs and chemicals}

Collagenase (CLS 4) was obtained from Sigma Chemicals Corp. (St. Louis, MO., USA). Bovine serum albumin was from ICN Biomedicals (High Wycombe, England). GIPantagonist ((Pro(3))GIP[mPEG]) was kindly provided by Professor PR Flatt, (University of Ulster, Coleraine, UK). All other chemicals were from Merck AG (Darmstadt, Germany). The radioimmunoassay kits for insulin and glucagon were from Diagnostika (Falkenberg, Sweden) and Eurodiagnostika (Malmö, Sweden), respectively.

\section{Experimental protocol}

All islet experiments were performed with mouse pancreatic islets isolated by retrograde injection of a collagenase solution via the bile-pancreatic duct [18-20]. The islets were collected under a stereomicroscope at room temperature, and transferred to incubation vials (12 islets per $1.0 \mathrm{ml}$ incubation buffer in each vial). They were then pre-incubated for $30 \mathrm{~min}$ at $37^{\circ} \mathrm{C}$ in $1 \mathrm{ml}$ of Krebs-Ringer bicarbonate (KRB) buffer, pH 7.4, supplemented with 10 $\mathrm{mmol} / \mathrm{l}$ HEPES and $0.1 \%$ bovine serum albumin and 1 $\mathrm{mmol} / \mathrm{l}$ glucose as previously described [18]. Each batch of islets was then gassed with $95 \% \mathrm{O}_{2}$ and $5 \% \mathrm{CO}_{2}$ to obtain constant $\mathrm{pH}$ and oxygenation. After pre-incubation, the buffer was changed to an identical medium in the presence or absence of different test agents (human serum, amino acids and/or GIP) and $8.3 \mathrm{mmol} / \mathrm{l}$ glucose. The KRB buffer was compensated for the glucose levels in the serum (measured separately) when the serum was added to the buffer to a final concentration of $8.3 \mathrm{mmol} / \mathrm{l}$. Islets were thereafter incubated for $60 \mathrm{~min}$ at $37^{\circ} \mathrm{C}$ in a shaking incubator (30 cycles per $\mathrm{min}$ ). Immediately after incubation, aliquots of the medium were removed for radioimmunoassay of insulin [21]. All experiments were performed in at least four replicates.

Serum from 6 healthy subjects was pooled yielding one sample for each time point and product (see human meal study above). Thereafter, the glucose, insulin, GIP and GLP-1 concentrations, as well as amino acid levels were analyzed in postprandial whey and control serum. The insulin concentrations present originally in the serum were subtracted from the concentrations obtained after the incubation with isolated islets in order to determine the amount of insulin secreted during the incubation.

Previous work has established that the plasma concentrations of isoleucine, leucine, valine, lysine and threonine are elevated following a whey meal [4]. The impact of each of these amino acids at a standard concentration of $4 \mathrm{mM}$ on insulin secretion from isolated islets was therefore examined. In addition, the effects of a cocktail consisting of $4 \mathrm{mM}$ of each amino acid with and without $100 \mathrm{nM}$ GIP were tested. These are standard concentrations used for in vitro work [22,23]. Furthermore, the stimulatory effects of whey serum (obtained at 0,15 and $30 \mathrm{~min}$ after meal ingestion) on insulin secretion was tested in vitro in the absence and presence of a $100 \mathrm{nM}$ GIP receptor antagonist ((Pro(3))GIP[mPEG]) using pooled serum from 12 healthy subjects (see human meal study, above).

\section{Statistical methods}

The results are expressed as means \pm SEM for the indicated number of observations. Probability levels of random differences were determined by analysis of variance followed by Tukey-Kramer's multiple comparisons test using GraphPad Prism ${ }^{\mathrm{TM}}$, (version 4.03; GraphPad Software Inc, San Diego, CA), when comparing the differences in insulin releasing capacities of whey and control serum, and to evaluate the effect of the GIP antagonist. Significant differences in insulin release among different amino acids were assessed by ANOVA followed by Tukey's multiple comparisons test (MINITAB, release 14.13; Minitab Inc, State Collage, PA). Differences resulting in $P<0.05$ were considered statistically significant.

\section{Results}

Post-prandial plasma response of amino acids, GIP and GLP-1

The mean plasma concentration of valine, isoleucine, leucine, threonine and lysine determined $0,15,30$ and 45 min after ingestion of whey and WWB, respectively, are presented in Figure 1. At $45 \mathrm{~min}$, the concentrations were 2.2-, 2.8-, 1.5-, 1.2- and 1.9-fold higher after ingestion of whey than WWB for leucine, isoleucine, valine, threonine and lysine, respectively. The plasma levels of both GIP and GLP-1 were 2 -fold higher at 30 and 45 min after ingestion of whey compared with WWB (Figure 2).

\section{Effects of post-prandial serum on in vitro insulin secretion}

We examined the effects of whey (grey bars) or control (white bars) serum samples obtained at 0, 7.5, 15, 30 and 45 min after ingestion of the meal on insulin secretion from freshly isolated mouse islets exposed to $8.3 \mathrm{mM}$ glucose (Figure 3). Whereas control serum was without effect on insulin secretion, whey serum obtained at 15 and $30 \mathrm{~min}$ after meal ingestion stimulated insulin secretion $>2.5$-fold.

\section{Effects of amino acids on in vitro insulin secretion}

We tested the effects of the five amino acids that are increased in response to whey (leucine, isoleucine, valine, threonine and lysine; cf. Figure 1). When tested at a concentration of $4 \mathrm{mM}$, only leucine $(+105 \%, P<0.05)$ evoked a statistically significant stimulation of insulin secretion relative that produced by glucose alone (Figure 4). A cocktail consisting of all five amino acids (each 

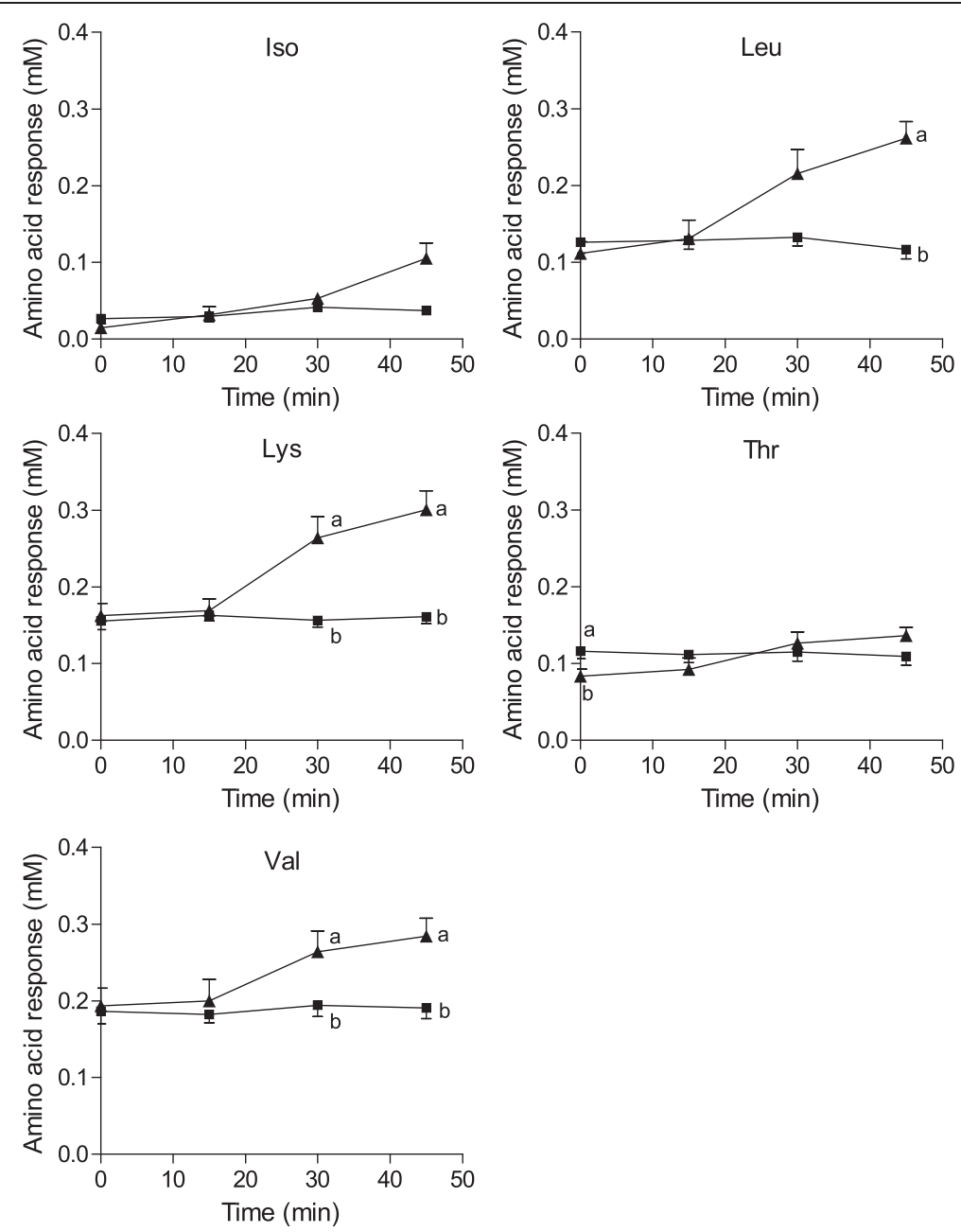

Figure 1 Amino acid responses in humans. Mean ( \pm SEM) values of isoleucine, leucine, valine, lysine and threonine in plasma obtained at different time points in response to the whey $(\mathbf{\Lambda})$ and WWB $(\mathbf{-})$ meal.

included at a concentration of $4 \mathrm{mM}$ ) increased insulin release beyond $(+270 \%, P<0.05)$ that obtained with glucose alone or any of the amino acids when they were tested individually. The effect of the cocktail was enhanced $\sim 2$-fold $(P<0.05)$ by GIP.

\section{Effects of a GIP antagonist on insulin secretion}

The stimulatory action of whey serum on insulin secretion, with or without added GIP-receptor antagonist, is seen in Figure 5. The insulin secretion, exceeding that produced by glucose alone, was significantly reduced in
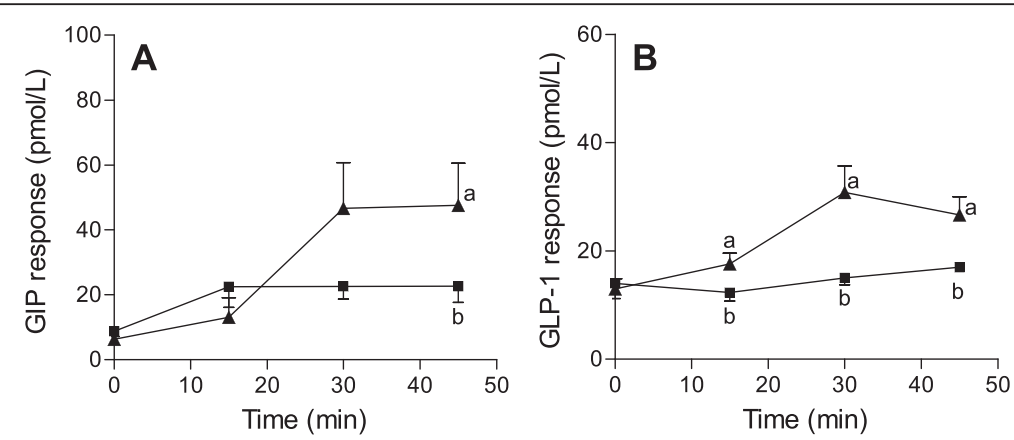

Figure 2 Incretin responses in humans. Mean ( \pm SEM) values of GIP (A) and GLP-1 (B) in plasma obtained at different time points in response to the whey $(\mathbf{\Lambda})$ and WWB (घ) meal. 


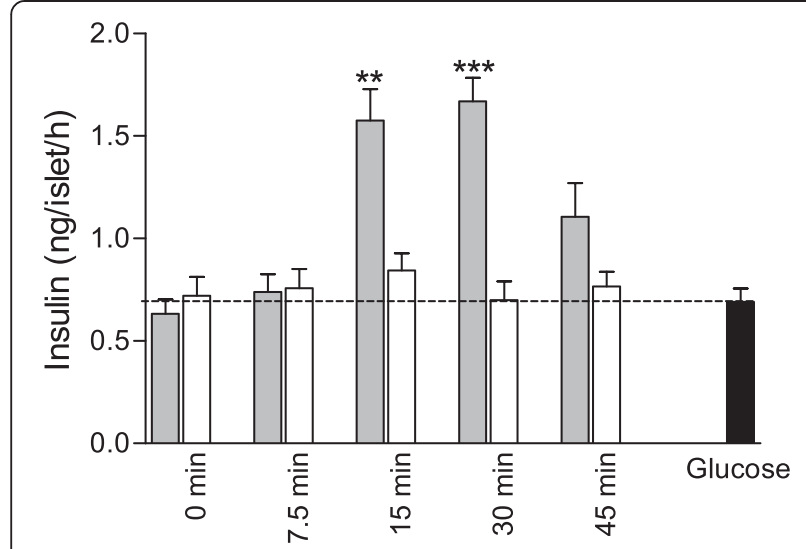

Figure 3 Insulin secretion of Langerhans islets incubated with human serum. Insulin secretion of isolated pancreatic islets incubated with serum obtained from healthy subjects after ingestion of whey (grey bars) and WWB (control, white bars), and $8.3 \mathrm{mM}$ glucose alone (reference, black bar). The islets were pooled from 8 different NMRI mice and values are means \pm SEM for 10 observations in each group performed at three different occasions. Significant differences between whey and control serum for each time point are denoted by ${ }^{* *} P<0.01,{ }^{* *} P<0.001$

the presence of the GIP-receptor antagonist $(100 \mathrm{nmol} /$ l) with $-56 \%$ at $15 \mathrm{~min}(P<0.05)$ and $-59 \%$ at $30 \mathrm{~min}$ $(P<0.01)$.

\section{Discussion}

In this study whey ingestion resulted in a 1.2 - to 2.8 fold increase in plasma concentration of leucine, isoleucine, valine, threonine and lysine relative the basal plasma levels and those obtained after ingestion of white wheat bread. It has previously been described that specific mixtures of amino acids do stimulate insulin secretion $[6,10]$. Thus, it is conceivable that the observed stimulation of insulin secretion is due to an increased level of the specific amino acids in vivo. The amino acid cocktail was shown to be superior to the single amino acids, with respect to in vitro insulin secretion, in support of such an opinion. Additionally, adding GIP to the amino acid cocktail further enhanced insulin stimulatory effect on the $\beta$-cells, indicating an involvement also of this incretin.

GIP as well as GLP-1 is a strong insulinotropic agent [24], and it has recently been reported that the two incretins have different effects on the insulin secretion, with GIP appearing to be more effective at normoglycemic levels and GLP-1 during hyperglycemia [25]. In previous studies we have demonstrated that whey protein affects GIP rather than GLP-1 $[4,6,14]$. Other studies have reported stimulation of GLP-1 as well [26] and in the present study whey protein clearly stimulated both GIP and GLP-1. Stimulation also of GLP-1 provides an alternative explanation for the insulinogenic action of

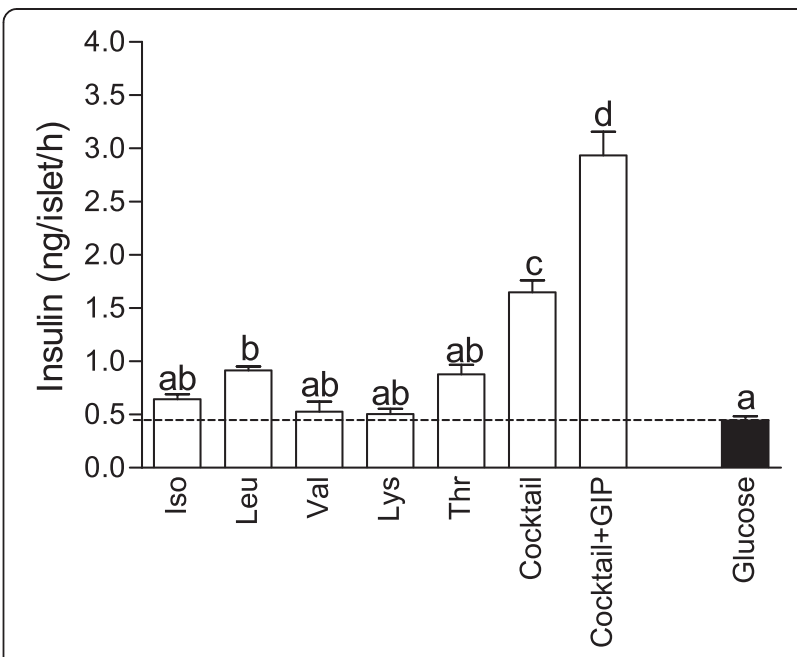

Figure 4 Insulin secretion of Langerhans islets incubated with amino acid. Insulin secretion from isolated pancreatic islets incubated at $8.3 \mathrm{mM}$ glucose in the absence or presence of leucine, isoleucine, valine, lysine and threonine, a cocktail of the 5 amino acids or a cocktail + GIP. Values are means \pm SEM for 8 observation in each group performed at three different occasions. The experiments were performed on the islets isolated and pooled from 6 different NMRI mice. Values with different letters are significantly different, $P<0.05$

whey. In the present study it was evident that whey ingestion increased the plasma concentration of incretins more than white wheat bread in healthy humans.

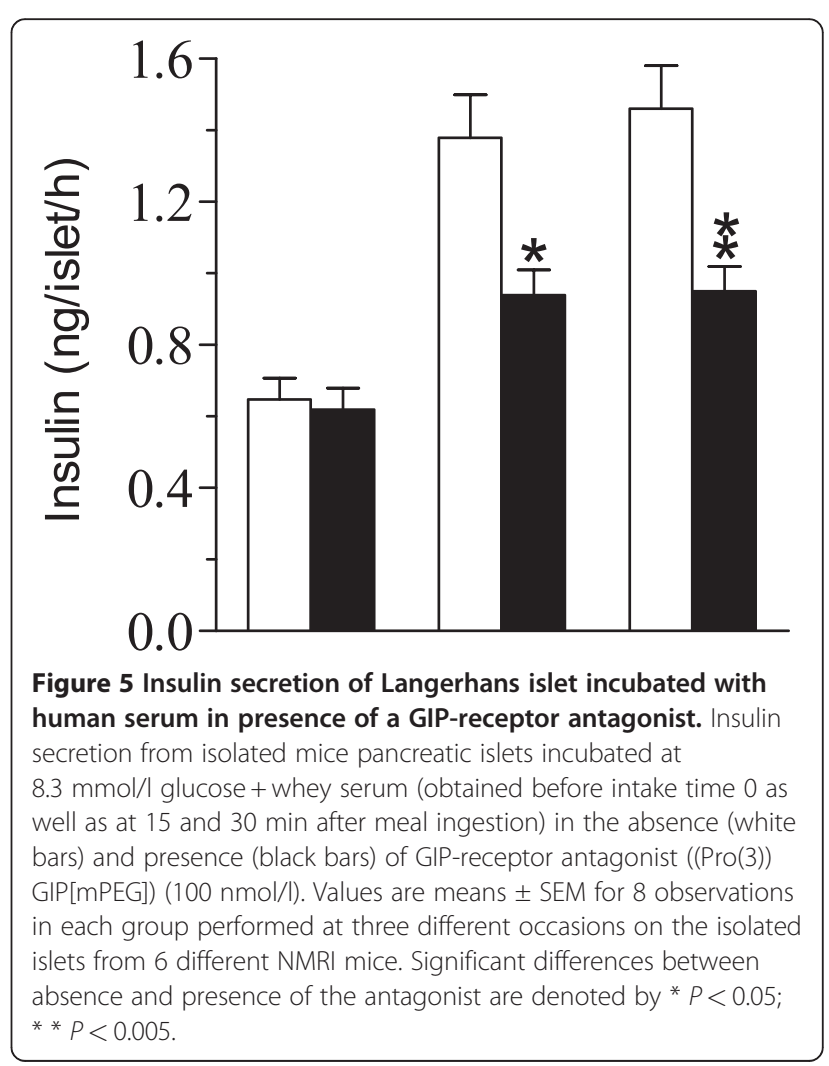


Further, addition of a GIP receptor antagonist decreased the in vitro insulinotropic action of whey serum significantly, and future work should address the mechanism by which whey enhances release of GIP from the enteric K-cells.

Insulin secretion in response to amino acids is interesting in terms of treatment of type-2 diabetes. Most of the insulinogenic amino acids trigger insulin secretion by mechanisms that differ from those utilized by glucose [27]. In type- 2 diabetes, the insulinogenic effects of amino acids may remain unaffected even after long-term diabetes [12,14,28]. Interestingly, addition of essential amino acids to a diet in poorly regulated elderly patients with type 2 diabetes improved metabolic control and lowered fasting blood glucose and serum insulin levels, as well as lowered levels of glycated hemoglobin (HbA1c) [29,30]. Possibly, the improved metabolic control results from increased muscle mass and improved insulin sensitivity, in addition to the insulinotropic effect of the amino acid supplementation.

A recent study identified the whey fraction, rather than the casein fraction, as the major insulin secretagogue in milk [4]. The different insulin-stimulating capacity of the whey and casein fractions may be secondary to differences in the rate of gastric emptying and digestion, with whey proteins being classified as rapidly released proteins $[31,32]$. It should be noted, however, that "whey serum" (i.e. obtained from subjects that had ingested whey protein) exerts a direct stimulatory effect on insulin secretion from isolated mouse islets. We therefore conclude that whey increases the plasma concentration of metabolites with insulinotropic capacity that act directly on the $\beta$-cells. In this context it is noteworthy that the stimulatory effect of the whey serum was strongest at 15 and $30 \mathrm{~min}$ after ingestion and that no stimulation was seen at $45 \mathrm{~min}$.

The stimulation of insulin release by the whey serum in vitro was not caused by any changes in glucose resulting from the addition of the serum samples, as this was adjusted for. Although several metabolic and hormonal parameters could be differentially modified in the serum from whey-ingested subjects, the observation that GIP was elevated may be of particular significance. Indeed, inclusion of the GIP-antagonist ((Pro(3)) GIP [mPEG]) in the incubation media markedly suppressed the stimulatory effects of the serum from whey-ingested subjects on insulin secretion from isolated islets. However, it should be emphasized that the results of present investigation illustrate an in vitro observation which needs to be verified in an appropriate in vivo animal model. Moreover, it will be interesting to confirm these observations using human islets to further study the differences or similarities in this context.
In conclusion, our work on isolated mouse pancreatic islets suggests that the insulinogenic capacity of whey proteins is mediated by postprandial elevation of specific plasma amino acids, and GIP. In addition, plasma GLP-1 levels were elevated and this may exert an additional stimulatory effect and the relative influence of the mediators of insulin secretion remains to be established.

\section{Abbreviations \\ GI: Glycemic index; GIP: Glucose-dependent insulinotropic polypeptide; GLP- 1: Glucagon-like peptide 1; II: Insulinemic index; WWB: White wheat bread.}

\section{Competing interest}

The authors declare that they have no competing interest.

\section{Authors' contribution}

AS was responsible for the in vitro studies and was involved in the evaluation and in writing the paper. UG coordinated the meal study and collected serum for the in vitro analysis and was involved in the evaluation and writing the paper. SJM was involved in the in vitro studies and in the evaluation. EÖ was involved in the study design and in the evaluation and in writing the paper. JJH was responsible for the incretin analysis and was involved in the evaluation. IB was responsible for securing the funding and was involved in the design and the evaluation and the writing of the paper. PR was involved in the design and the evaluation and writing of the paper. All authors read and approved the final manuscript.

\section{Acknowledgements}

This study was supported by grants from Direktör Albert Påhlssons foundation for research and charity. The technical assistance of Britt-Marie Nilsson is gratefully acknowledged.

\section{Author details}

'Lund University Diabetes Centre, Clinical Research Centre, University Hospital, Lund University, Lund, Sweden. ${ }^{2}$ Department of Applied Nutrition and Food Chemistry, Lund University, Lund, Sweden. ${ }^{3}$ Department of Medical Physiology, The Panum Institute, University of Copenhagen, Copenhagen, Denmark. ${ }^{4}$ Oxford Centre for Diabetes, Endocrinology and Metabolism, Oxford University, Oxford OX3 7LJ UK. ${ }^{5}$ Applied Nutrition and Food Chemistry, Lund University, P.O. Box 124, 22100 Lund, Sweden.

Received: 2 December 2011 Accepted: 18 April 2012

Published: 30 May 2012

\section{References}

1. Östman EM, Liljeberg Elmståhl HGM, Björck IME: Inconsistency between glycemic and insulinemic responses to regular and fermented milk products. Am J Clin Nutr 2001, 74:96-100.

2. Nilsson M, Elmstahl H, Bjorck I: Glucose and insulin responses to porridge and gruel meals intended for infants. Eur J Clin Nutr 2005, 59:646-650.

3. Liljeberg Elmståhl H, Björck l: Milk as a supplement to mixed meals may elevate postprandial insulinaemia. Eur J Clin Nutr 2001, 55:994-999.

4. Nilsson M, Stenberg M, Frid AH, Holst JJ, Björck IM: Glycemia and insulinemia in healthy subjects after lactose-equivalent meals of milk and other food proteins: the role of plasma amino acids and incretins. Am J Clin Nutr 2004, 80:1246-1253.

5. Khan MA, Gannon MC, Nuttall FQ: Glucose appearance rate following protein ingestion in normal subjects. J Am Coll Nutr 1992, 11:701-706.

6. Nilsson M, Holst JJ, Bjorck IME: Metabolic effects of amino acid mixtures and whey protein in healthy subjects: studies using glucose-equivalent drinks. Am J Clin Nutr 2007, 85:996-1004.

7. Krebs M, Brehm A, Krssak M, Anderwald C, Bernroider E, Nowotny P, Roth $E_{\text {, }}$ Chandramouli V, Landau BR, WaldhausI W, Roden M: Direct and indirect effects of amino acids on hepatic glucose metabolism in humans. Diabetologia 2003, 46:917-925.

8. Fajans SS, Floyd JC Jr, Knopf RF, Conn FW: Effect of amino acids and proteins on insulin secretion in man. Recent Prog Horm Res 1967, 23:617-662.

9. Floyd JC Jr, Fajans SS, Conn JW, Knopf RF, Rull J: Stimulation of insulin secretion by amino acids. J Clin Invest 1966, 45:1487-1502. 
10. Schmid R, Schusdziarra V, Schulte-Frohlinde E, Maier V, Classen M: Role of amino acids in stimulation of postprandial insulin, glucagon, and pancreatic polypeptide in humans. Pancreas 1989, 4:305-314.

11. Schmid R, Schulte-Frohlinde E, Schusdziarra V, Neubauer J, Stegmann M, Maier V, Classen M: Contribution of postprandial amino acid levels to stimulation of insulin, glucagon, and pancreatic polypeptide in humans. Pancreas 1992, 7:698-704.

12. Van Loon LJ, Kruijshoop M, Menheere PP, Wagenmakers AJ, Saris WH, Keizer HA: Amino Acid ingestion strongly enhances insulin secretion in patients with long-term type 2 diabetes. Diabetes Care 2003, 26:625-630.

13. Gannon MC, Nuttall FQ: Amino acid ingestion and glucose metabolism-A review. IUBMB Life 2010, 62:660-668,

14. Frid AH, Nilsson M, Holst JJ, Bjorck IME: Effect of whey on blood glucose and insulin responses to composite breakfast and lunch meals in type 2 diabetic subjects. Am J Clin Nutr 2005, 82:69-75.

15. Stenberg M, Marko-Varga G, Oste R: Enantioseparation of $d$ - and I-amino acids by a coupled system consisting of an ion-exchange column and a chiral column and determination of d-aspartic acid and d-glutamic acid in soy products. Food Chem 2002, 79:507-512.

16. Krarup T, Madsbad S, Moody AJ, Regeur L, Faber OK, Holst JJ, Sestoft L: Diminished immunoreactive gastric inhibitory polypeptide response to a meal in newly diagnosed type I (insulin-dependent) diabetics. J Clin Endocrinol Metab 1983, 56:1306-1312.

17. Orskov C, Rabenhoj L, Wettergren A, Kofod H, Holst JJ: Tissue and plasma concentrations of amidated and glycine-extended glucagon-like peptide I in humans. Diabetes 1994, 43:535-539.

18. Salehi A, Chen D, Hakanson R, Nordin G, Lundquist I: Gastrectomy induces impaired insulin and glucagon secretion: evidence for a gastro-insular axis in mice. J Physiol 1999, 514(Pt 2):579-591.

19. Salehi A, Vieira E, Gylfe E: Paradoxical Stimulation of Glucagon Secretion by High Glucose Concentrations. Diabetes 2006, 55:2318-2323.

20. Lundquist I, Panagiotidis G, Salehi A: Islet acid glucan-1,4-alphaglucosidase: a putative key enzyme in nutrient-stimulated insulin secretion. Endocrinology 1996, 137:1219-1225.

21. Panagiotidis G, Salehi AA, Westermark P, Lundquist I: Homologous islet amyloid polypeptide: effects on plasma levels of glucagon, insulin and glucose in the mouse. Diabetes Res Clin Pract 1992, 18:167-171.

22. Jimenez-Feltstrom J, Salehi A, Meidute Abaraviciene S, Henningsson R, Lundquist I: Abnormally decreased NO and augmented CO production in islets of the leptin-deficient ob/ob mouse might contribute to explain hyperinsulinemia and islet survival in leptin-resistant type 2 obese diabetes. Regul Pept 2011, 170:43-51.

23. Trümper A, Trümper $K$, Trusheim H, Arnold R, Göke B, Hörsch D: Glucose-Dependent Insulinotropic Polypeptide Is a Growth Factor for $\beta$ (INS-1) Cells by Pleiotropic Signaling. Mol Endocrinol 2001, 15:1559-1570.

24. Asmar M, Holst JJ: Glucagon-like peptide 1 and glucose-dependent insulinotropic polypeptide: new advances. Curr Opin Endocrinol Diabetes Obes 2010, 17:57-62

25. Yabe D, Seino Y: Two incretin hormones GLP-1 and GIP: Comparison of their actions in insulin secretion and [beta] cell preservation. Prog Biophys Mol Biol. In Press, Corrected Proof.

26. Veldhorst MAB, Nieuwenhuizen $A G$, Hochstenbach-Waelen A, van Vught AJAH, Westerterp KR, Engelen MPK, Brummer R-JM, Deutz NEP, WesterterpPlantenga MS: Dose-dependent satiating effect of whey relative to casein or soy. Physiol Behav 2009, 96:675-682.

27. Ronner P, Naumann CM, Friel E: Effects of glucose and amino acids on free ADP in betaHC9 insulin-secreting cells. Diabetes 2001, 50:291-300

28. Zander M, Madsbad S, Madsen JL, Holst JJ: Effect of 6-week course of glucagon-like peptide 1 on glycaemic control, insulin sensitivity, and beta-cell function in type 2 diabetes: a parallel-group study. Lancet 2002, 359:824-830.

29. Solerte SB, Fioravanti M, Locatelli E, Bonacasa R, Zamboni M, Basso C, Mazzoleni A, Mansi V, Geroutis N, Gazzaruso C: Improvement of Blood Glucose Control and Insulin Sensitivity During a Long-Term (60 Weeks) Randomized Study with Amino Acid Dietary Supplements in Elderly Subjects with Type 2 Diabetes Mellitus. Am J Cardiol 2008, 101:S82-S88.

30. Solerte SB, Gazzaruso C, Bonacasa R, Rondanelli M, Zamboni M, Basso C, Locatelli E, Schifino N, Giustina A, Fioravanti M: Nutritional Supplements with Oral Amino Acid Mixtures Increases Whole-Body Lean Mass and
Insulin Sensitivity in Elderly Subjects with Sarcopenia. Am J Cardio/ 2008 101:S69-S77.

31. Boirie $Y$, Dangin M, Gachon P, Vasson M-P, Maubois J-L, Beaufrére B: Slow and fast dietary proteins differently modulate postprandial protein accretion. Proc Natl Acad Sci 1997, 94:14930-14935.

32. Calbet JA, Holst JJ: Gastric emptying, gastric secretion and enterogastrone response after administration of milk proteins or their peptide hydrolysates in humans. Eur J Nutr 2004, 43:127-139.

doi:10.1186/1743-7075-9-48

Cite this article as: Salehi et al:: The insulinogenic effect of whey protein is partially mediated by a direct effect of amino acids and GIP on $\beta$-cells. Nutrition \& Metabolism 2012 9:48.

\section{Submit your next manuscript to BioMed Central and take full advantage of:}

- Convenient online submission

- Thorough peer review

- No space constraints or color figure charges

- Immediate publication on acceptance

- Inclusion in PubMed, CAS, Scopus and Google Scholar

- Research which is freely available for redistribution

Submit your manuscript at www.biomedcentral.com/submit
C Biomed Central 